\title{
Financial TechnologyReadiness: Strategic Innovation Management in the Service Industry 4.0
}

\author{
J T Purba ${ }^{1}$, H Hery ${ }^{2}$, V N S Lestari ${ }^{3}$ \\ \{john.purba@uph.eduand jpoerba88@gmail.com ${ }^{1}$, hery.fik@uph.edu ${ }^{2}$, venugra@unitomo.ac.id $\left.{ }^{3}\right\}$ \\ ${ }^{1}$ Faculty of Economics and Business Universitas Pelita Harapan, Indonesia \\ ${ }^{2}$ Faculty of Computer Science Universitas Pelita Harapan, Indonesia \\ ${ }^{3}$ Faculty of Economics and Business Universitas Dr. Soetomo, Surabaya, Indonesia
}

\begin{abstract}
The Collaboration of Financial technology readiness on banks and financial institutions with fin-tech services in Indonesia. These fin-tech service companies are developing various kinds of products, establishing partnerships, and providing convenient services to encourage financial inclusion. The aim of this study is to contribute and to respond how the 4.0 technology Readiness ofdigitization in Financial business issues. The customer preferences, particularly amongst millennials and "digital natives" with regard to convenience and or not convenience due to the speed and cost of financial services are increasingly high demand. This research took time 5 months with a number of millennial respondents who already use day to day Fin-tech transaction in the area of greater Jakarta. The quantitative analysis technique is used to present the findings and discussion. Findings proved that; first the readiness using Fin-tech in the growing emerging digital market of the national economy. Second, Financial technology, related to the internet of things, computing power, mobile technology, and big data, has been proven driver of innovation strategy management in financial technology services. In conclusion, the avail of Fin-tech infrastructure will give Strategic Innovationin managing the opportunities for new business sectors related.
\end{abstract}

Keywords: Fin-tech, Readiness, Strategic Innovation, Service Industry 4.0.

\section{Introduction}

Globalization economy impacted by digital technology of 4.0 era makes the world seems borderless: any happens in one big country can be influenced many countries over the world[1]. Indonesia is one the country which promising market for Fin-tech startups to grow in this globe. Here they are not too constrained by regulations and can develop faster than traditional financial institutions. But we see fin-tech startups in Indonesia not the best in terms of innovation, if we compare them to services in other countriestrading is an economic activity that requires high accuracy in its application. Financial technology/Fin-tech is the result of a combination of financial services and technology that ultimately changes the conventional business model to moderate, which initially pays face-to-face and carries a certain amount of cash, can now make long-distance transactions by making payments that can be made in a matter of just seconds [2]. The financial services industry in this country is also significantly changing from time to time due to digital transformation development. The latter has forced new and the existing organizations, as well as companies, have to innovate their value propositions and services, their internal processes, do to engage with their 
customers[3], [4]. The application of information systems service strategy is challenging to solve the problems of appropriate resources with related to information technology vendors, suppliers, in responding to the needs of internal customers and clients [5]. BI Regulation on Fintec. Fin-tech poses both opportunities and challenges for traditional financial institutions and their regulators. Fin-tech companies may be competitors for banks' loan and payment customers, and it may partner with banks to increase efficiency[6]. ICT becomes main tool to implement the companies' readiness to the new technology contributing to organizational effectiveness in running the companies and or organizations. Fin-tech providers appear regularly, proposing relief of customers' pain points.

Regulators must decide on activity-based versus entity-based regulation to secure the customers. The fin-tech Regulation course is designed to provide participants an opportunity for in-depth discussion of Fin-tech, potential areas of application for new technologies, challenges, and risks. It will also provide an opportunity for participants to develop a better understanding of the fin-tech ecosystem. This course will consider how the financial services landscape may be transformed by the widespread adoption of financial technology and how central banks and regulators can mitigate potential risks to financial stability and integrity without stifling innovation[7].

World Fin-tech Report, (2017) reports that fin-tech companies have brought significant changes in customer relationships. Globally, half of the customers $(50.2 \%)$ stated that they use financial services at least one non-traditional company for banking, insurance, payment, or investment management with the highest percentage being Asia Pacific $(58.5 \%)[8]$.

Fig. 1. Financial Technology fusion and services[9]

\section{IINANCIAL TECHNOLOGY}

(B) BANK INDONESIA

Financial Technology (FinTech) is a fusion between Financial and Technology Services which can also support reaching the unbanked people...

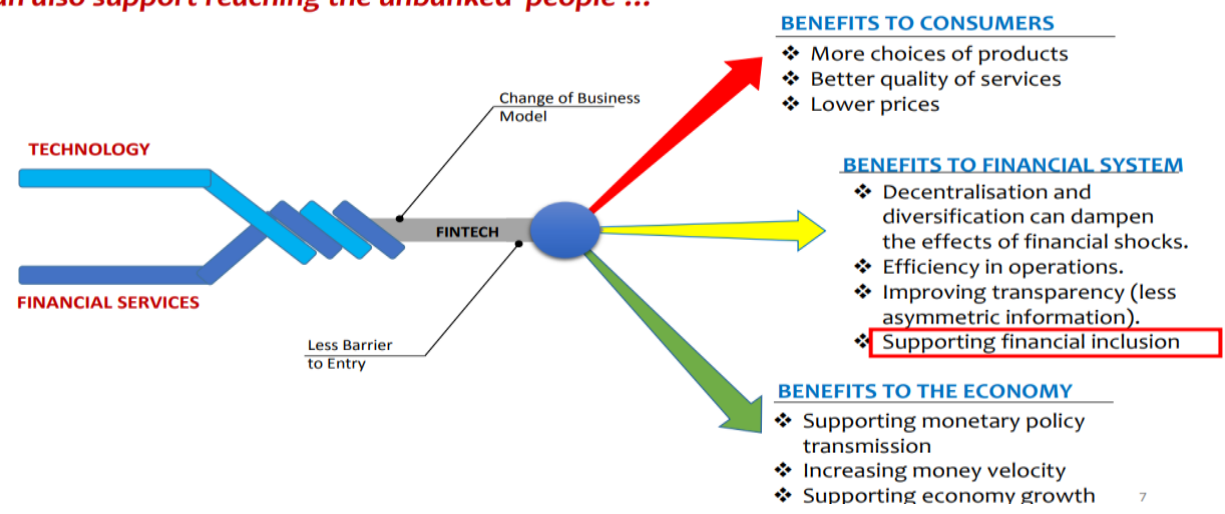

Through PBI No.19 / 12 / PBI / 2017 concerning the Implementation of Financial Technology, Bank Indonesia regulates the obligation to register at Bank Indonesia for Financial Technology Administrators who carry out payment system activities. The registration obligation is excluded for Payment System Service Providers who have obtained licenses from Bank Indonesia and for Financial Technology Administrators who are under the authority of other authorities[2], [10]. Furthermore, Bank Indonesia 
will announce Financial Technology Providers that have been registered on the official website of Bank Indonesia. The registration obligation does not eliminate the obligation of the Financial Technology Provider to submit licenses to Bank Indonesia or the relevant authorities.

Table 1:Development of the Number of Electronic Money Holders in DFS Agents (Million

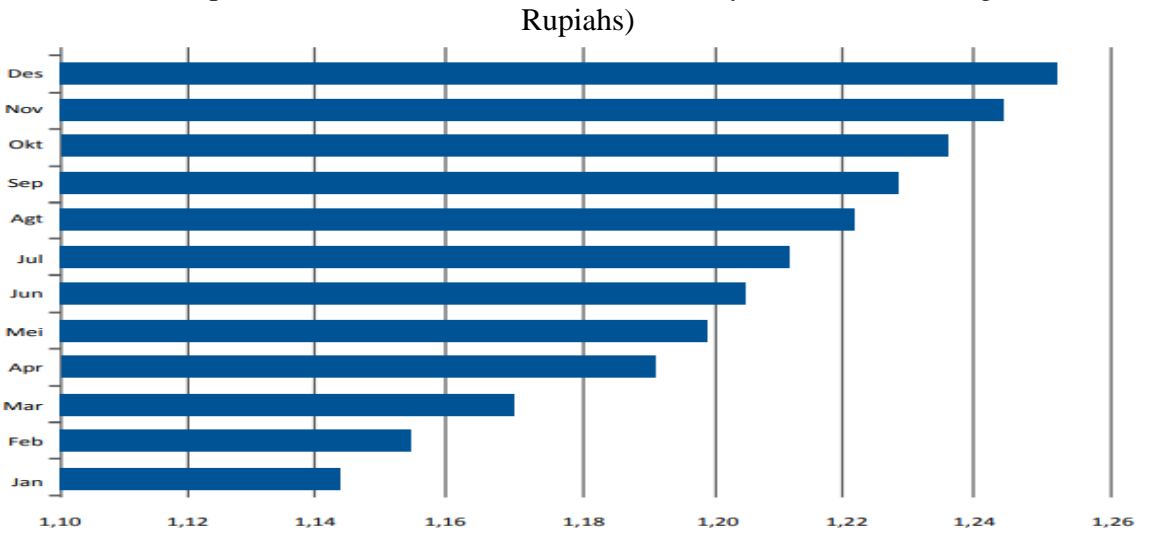

Source: Bank Indonesia, December 2016

E-commerce as part ICT application is also present to provide solutions and convenience for both parties so that business activities become more extensive and unlimited for the organizations [11]-[13]. Thus, nowadays e-commerce, currently technology players are "shocked" by the presence of a new industry called financial technology or familiarly known as Fin-tech Indonesia. The purpose of the Fin-tech company itself is to make it easier for the public to access financial products, facilitate financial transactions, and also improve the community's understanding of financial literacy. In developed countries, Fin-tech companies are divided into two segments, namely retail companies and also large companies. Whereas in Indonesia itself has many types where companies that do so are dominated by startup companies, such as for payments, lending or lending, retail investment, crowdfunding, financial planning, financial research, and also remittances.

The rapid growth of fin-tech in Indonesia is marked by the formation of the Indonesian Fin-tech Association which has been legally registered as a legal entity. Fin-tech companies in Indonesia consist of fin-tech companies, financial companies, or other financial institutions that have expertise and interest in the field of financial technology. The company has a shared vision of realizing the future of digital technology-oriented financial services aimed at Indonesian people who are pleased and interested. The transaction of Fin-tech in this country will be displayed as the following figure; 


\section{FINTECH NOWADAYS}

While FinTech Transaction in Indonesia $2017 \pm$ USD18,6 billion, 99\% of it is in digital payments area accordance to the number of FinTech players which majority in Payment, Clearing, and Settlement area...

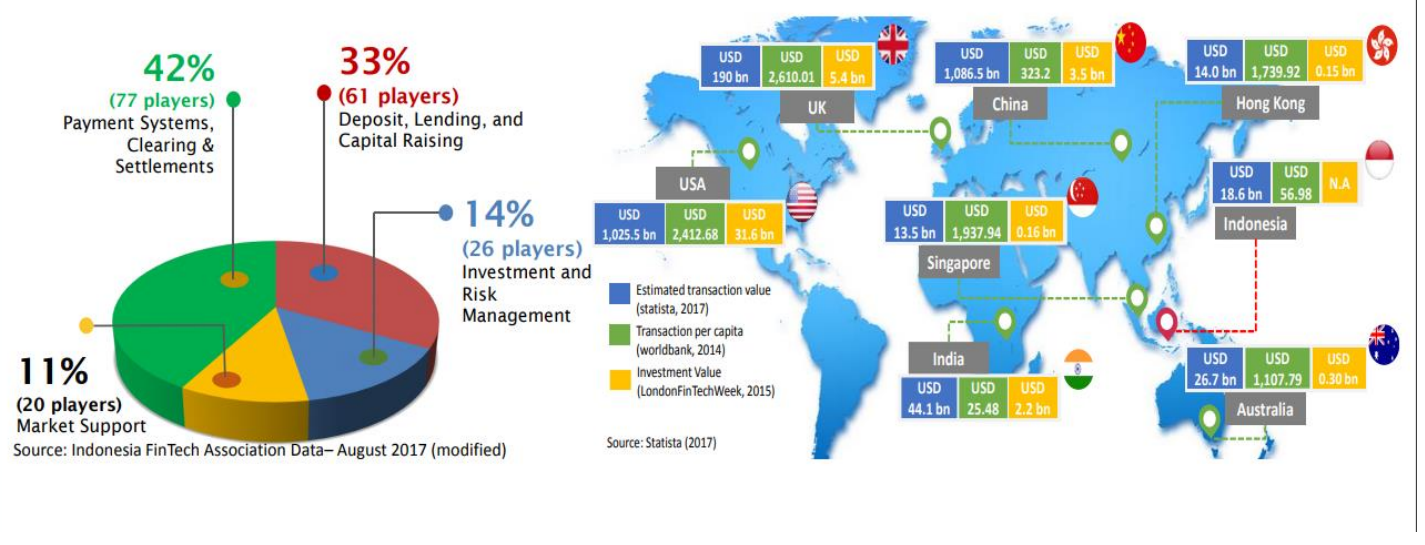

Fig. 2: Fin-techTransaction Nowadays in Indonesia[9]

Following is a list of fin-tech lending companies registered with OJK:

1. Danamas 2. Amartha 3. Koinworks 4. KlikACC 5. Modalku 6. Danacepat 7. AwanTunai 8. Investree, 9. CROWDO, 10. Akseleran, 11. UangTeman, 12. Dompet Kilat, 13. Taralite, 14. FINTAG, 15. Invoila, 16. KIMO, 17. TunaiKita, 18. Igrow, 19. Cicil, 20. Dana Merdeka, 21. Cash Wagon, 22. Esta Kapital, 23. Ammana, 24. Gradana, 25. Dana Mapan, 26. Aktivaku, 27. Danakini, 28. Finmas, 29. Rupiah Plus, 30. Tokomodal, 31. Indodana, 32. Kredivo, 33. Mekar.id, 34. PinjamanGo, 35. Iternak.id, 36. Kredit Pintar, 37. Kredito, 38. Crowde, 39. PinjamGampang, 40. TaniFund, 41. Danain, 42. Indofund.id, 43. SPGIndonesia, 44. KreditPro, 45. Avantee, 46. Do-it, 47. RupiahCepa, 48. Danarupiah. 49. Danabijak,50. Cashcepat, 51. Danalaut, 52. Danasyariah, 53. Telefin, 54. Modalrakyat, 55. Kawancicil, 56. Sanders One Stop Solution, 57. Kreditcepat, 58. Uangme, 59. Pinjam Duit, 60. Pinjam Yuk, 61. Pinjam Modal, 62. Julo, 63. Easy Cash, 64. Maucash, 65. RupiahOne, 66. Pohon Dana, 67. Dana Cita, 68. DANAdidik, 69. TrustIQ, 70. Danai, 71. Pinduit, 72. Pinjam, 73. Danamart, 74. SAMAKITA, 75. Saya Modalin, 76. PLAZA PINJAMAN, 77. Vestia P2P Lending Platform, 78. Singa, 79. AdaKami, 80. ModalUsaha, 81. Asetku, 82. Danafix, 83. Lumbung Dana, 84. Lahansikam, 85. Modal Nasional, 86. Dana Bagus, 87. ShopeeKredit, 88. Ikredo online, 89. AdaKita, 90. UKU, 91. Pinjamwinwin, 92. Pasarpinjam, 93. Kredinesia, 94. BKDana, 95. GandengTangan.org, 96. Modalantara, 97. Komunal, 98. ProsperiTree, 99. Danakoo[14]. 


\section{Literature Review}

There are several definitions of fin-tech explained by many, but generally fin-tech can be defined as technological innovation in financial services. Financial service providers are developing technology that disrupts traditional financial markets by developing new and sophisticated applications to be used in various types of payments to more complex applications for artificial intelligence and big data[2].

Kawai, Secretary General of the International Insurance Supervisory Association, a Financial Stability Board (FSB) member organization defines fin-tech as a technology that enables innovation in financial services. This has led to new business models, applications, processes and products in financial services that can have a material impact on financial markets and institutions and the provision of financial services[15].Definitions of the Fin-tech also connected meritsto the serve the purposes of the authors' research or business objectives of their perspectives. As described by Arner, Buckley and Barberis were some of the first scholars to examine the evolution of fin-tech using about definition of the term that proposed that all incumbent and new financial companies and industry participants could be regarded as fin-tech, regardless of their size of business model or product portfolio. Their approach is useful in the area of research that employs an evolutionary of perspective accordingly, as the development of financial technologies are classified into three major, sequential phases[12], [16], [17].

\section{FinTech RISK MAPPING}

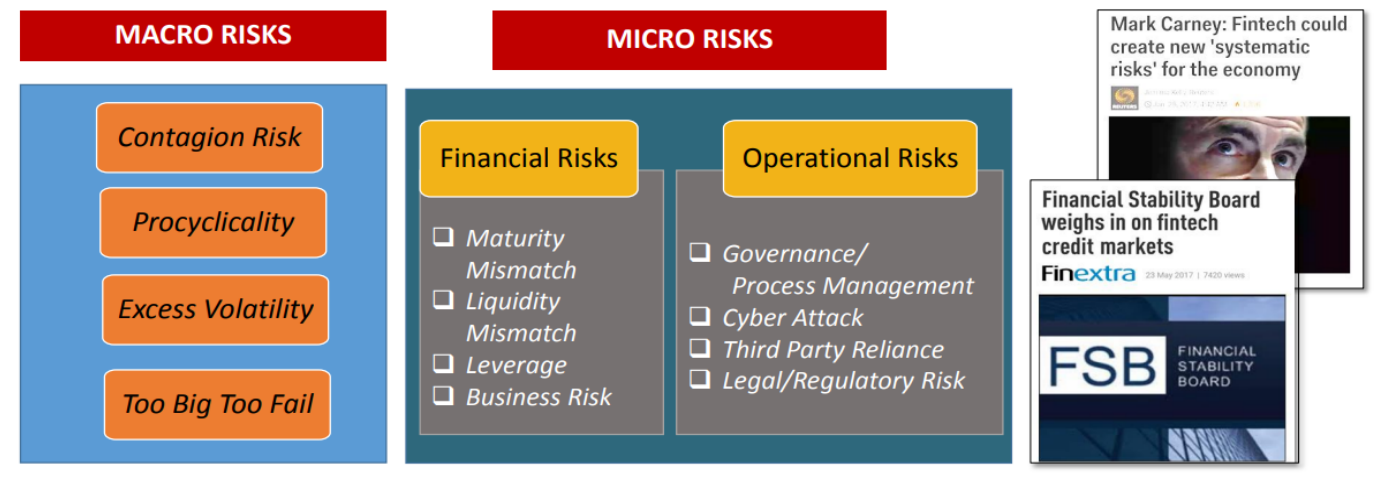

Fig.3. Fin-tech Risk Mapping[9]

ICT innovation becoming one of the compulsory tools in any enterprises, business companies and other organizations, where the results are more effective and efficient but shall consider about the risks accordingly. For industries where information itself a product, we would expect to see an increasing number of IT applications that pertain directly to the product. Such differences, if in fact true, should be reflected in the events discussed by the CEO in the annual report[18]. 


\section{Method}

\subsection{Sample}

The populations for this research were millennial consumers in Jakarta, Bogor, Depok, Tangerang and Bekasi (Jabodetabek) in Java Island Indonesia. This research used the sampling method with non-parametric with purposive sampling technique where only give opportunity the ones of the millennial generations who ever used or familiar with Fin-tech were preferred. This research was conducted by distributing the questionnaires to a number of respondents who use Fin-tech in Jabodetabek but only 176 respondents returned to researchers.

\subsection{Measurement}

The instrument based on TRI [19] and the TAM [20]. The four TRI factors, including optimism, innovativeness, insecurity, and discomfort, were taken and modified from Meng et al. [21]. This study cross-culturally involving millennial respondents of tribes in Greater Jakarta. The TRI scalerevealed appropriate reliability, validity and reliability. Due to the Indonesian respondents, the items are originally written in English, for distributing to them firstly translated into Indonesian. All items were assessed on a five-point Likert scale, ranging from strongly disagree (1) until strongly agree (5). However, the actual usage of running apps was coded as a continuous variable.

\subsection{Analysis}

Since this study applied an existing theoretical model (TRI) to predict individuals 'behavior, consist of the millennial respondents, using the digital payment perception, this research is considered an appropriate approach for this study. Following the guideline of Hair et al. [22], data analysis was performed in two phases. First, this study assessed the validity and reliability of the measures used, including indicator reliability, internal consistency reliability, convergent validity, and discriminant validity. Second, Coefficient Determination and multiple regressions were evaluated by examining collinearity, $\mathrm{R} 2$ explanation of endogenous latent variables, and the significance and relevance of path coefficients. Then, the results obtained show how classified the hierarchy of each variable in this study. This research uses quantitative method. The research data were collected using a survey. A questionnaire was distributed to 176 respondents. The sampling used nonparametric method with a purposive sampling approach. Considering that finance technology is still limited, only those who have used Fintech applications were involved. This was suggested by Imam Gozali who stated that respondents could only give data needed for further analysis from a group with certain characteristics [23]. The characteristics of the respondents are men/women in the age of millennial, and the users of Fin-tech applications are those who had already familiar using the transactions of Fin-tech applications. Having the collected the data, then analyzed with Quantitative analysis, Multiple Regression by using the IBM SPSS 24.0 software application.

\section{Discussion and Findings.}

\subsection{Validity Analysis and Reliability of Questionnaires.}

Based on data as many as 176 respondents from 325 distributed, carried out validity and reliability tests. The purpose of this test is to find out whether the data obtained from the questionnaire has met the required level of validity and reliability. Test the validity of using 
Pearson correlation while the reliability test uses the Cronbach's Alpha coefficient. The calculation uses the IBM SPSS 24 program, and the results can be seen in Table 2.

Table-2. Validity Test Results and Reliability Factors to Test Someone's Readiness using Fintech

\begin{tabular}{|c|c|c|c|}
\hline Dimension & Items of Indicators & Pearson Correlation & Cronbach's Alpha \\
\hline \multirow[t]{10}{*}{ Optimism } & $\mathrm{X} 1$ & $684(* *)$ & \multirow[t]{10}{*}{, 817} \\
\hline & $\mathrm{X} 2$ & $685(* *)$ & \\
\hline & $\mathrm{X} 3$ & $485(* *)$ & \\
\hline & $\mathrm{X} 4$ &, $715(* *)$ & \\
\hline & $\mathrm{X} 5$ & $618(* *)$ & \\
\hline & $\mathrm{X} 6$ & $752(* *)$ & \\
\hline & $\mathrm{X} 7$ & 549 (**) & \\
\hline & $\mathrm{X} 8$ &, $547(* *)$ & \\
\hline & X9 & $654(* *)$ & \\
\hline & $\mathrm{X} 10$ & 480 (**) & \\
\hline \multirow{7}{*}{$\begin{array}{l}\text { Innovative- } \\
\text { ness }\end{array}$} & $\mathrm{X} 1$ & $463(* *)$ & \multirow[t]{7}{*}{670} \\
\hline & $\mathrm{X} 2$ & ,371(**) & \\
\hline & $\mathrm{X} 3$ & $632(* *)$ & \\
\hline & $\mathrm{X} 4$ & $675(* *)$ & \\
\hline & $\mathrm{X} 5$ & $643(* *)$ & \\
\hline & $\mathrm{X} 6$ & $757(* *)$ & \\
\hline & $\mathrm{X} 7$ & $490(* *)$ & \\
\hline \multirow[t]{9}{*}{ Discomfort } & $\mathrm{X} 1$ &, $589(* *)$ & \multirow[t]{9}{*}{, 713} \\
\hline & $\mathrm{X} 2$ & $608(* *)$ & \\
\hline & $\mathrm{X} 3$ & 470 (**) & \\
\hline & $\mathrm{X} 4$ & $575(* *)$ & \\
\hline & $\mathrm{X} 5$ & $394(* *)$ & \\
\hline & $\mathrm{X} 6$ &, $427(* *)$ & \\
\hline & $\mathrm{X} 7$ &, $557(* *)$ & \\
\hline & $\mathrm{X} 8$ & $519(* *)$ & \\
\hline & vo & $522(* *)$ & \\
\hline \multirow[t]{9}{*}{ Insecurity } & $\mathrm{X} 1$ & ,493(**) & \multirow[t]{9}{*}{,767 } \\
\hline & $\mathrm{X} 2$ &, $589(* *)$ & \\
\hline & $\mathrm{X} 3$ &, $525(* *)$ & \\
\hline & $\mathrm{X} 4$ &, $592(* *)$ & \\
\hline & $\mathrm{X} 5$ & $657(* *)$ & \\
\hline & $\mathrm{X} 6$ &, $743(* *)$ & \\
\hline & $\mathrm{X} 7$ &, $550(* *)$ & \\
\hline & $\mathrm{X} 8$ & $563(* *)$ & \\
\hline & $\mathrm{X} 9$ & $617(* *)$ & \\
\hline \multirow{6}{*}{$\begin{array}{l}\text { Perceived of } \\
\text { usefulness }\end{array}$} & $\mathrm{X} 1$ &, $728(* *)$ & \multirow[t]{6}{*}{861} \\
\hline & $\mathrm{X} 2$ & $844(* *)$ & \\
\hline & $\mathrm{X} 3$ &, $724(* *)$ & \\
\hline & $\mathrm{X} 4$ &, $771(* *)$ & \\
\hline & $\mathrm{X} 5$ &, $759(* *)$ & \\
\hline & $\mathrm{X} 6$ & $791(* *)$ & \\
\hline \multirow{6}{*}{$\begin{array}{l}\text { Perceived ease } \\
\text { of use }\end{array}$} & $\mathrm{X} 1$ & $576(* *)$ & \multirow[t]{6}{*}{,781 } \\
\hline & $\mathrm{X} 2$ & 603 (**) & \\
\hline & $\mathrm{X} 3$ &, $653(* *)$ & \\
\hline & $\mathrm{X} 4$ & $813(* *)$ & \\
\hline & $\mathrm{X} 5$ &, $792(* *)$ & \\
\hline & $\mathrm{X} 6$ &, $696(* *)$ & \\
\hline
\end{tabular}

*Correlation is significant at 0.05 levels (2-tailed). 
Validity test is done by correlating each item statement in each dimension with the total value of the construct in a dimension. Validity test is done using Pearson correlation with conditions $>0.3$. Based on Table-1 it can be seen that all items of statements from the dimensions of optimism, innovativeness, discomfort, insecurity, perceived usefulness, and perceived ease of use are valid. That is because the correlation value of each item statement has exceeded the requirements, namely $>0.3 * *$ Correlation is significant at the 0.01 level (2tailed).

Then the Reliability testing is done by measuring the consistency of all statement items in a construct. Reliability testing is done using the Cronbach's Alpha coefficient with terms> 0.6. Based on Table-1 it can be seen that all dimensions which include dimensions of optimism, innovativeness, discomfort, insecurity, perceived usefulness, and perceived ease of use are reliable. That is because the value of the Cronbach's Alpha coefficient for each dimension has exceeded the requirements of $>0.6$.

\subsection{Descriptive Analysis of Factors to Test Someone's Readiness in using a Fin-tech Application}

The following is a descriptive analysis of the factors to test a person's readiness in technology on the Fin-tech application. These factors consist of 6 dimensions, namely optimism, innovativeness, discomfort, insecurity, perceived usefulness, and perceived ease of use. The optimism dimension consists of 10 item statements, the innovativeness dimension consists of 7 item statements, the discomfort dimension consists of 10 item statements, the insecurity dimension consists of 9 item statements, the perceived usefulness dimension consists of 6 item statements, and the perceived ease of use dimension consists of 6 item statement. The results of the descriptive statistics from the respondents 'answers used in this study are to find the average value (mean) of respondents' responses for each statement item and dimension. After that, it is necessary to give class limits for each dimension in the form of categories that aim to make it easier for researchers to determine the mean categorization. Class limits in the form of these categories use 5 Likert Scales. To find out the limit of value per each class, the formula for scale ranges is used in the following percentages:

$\mathrm{RS}=(\mathrm{m}-\mathrm{n}) / \mathrm{b}$

Where: $\mathrm{m}=$ highest value

$\mathrm{n}=$ lowest value

$\mathrm{b}=$ number of classifations

Table-3.Classification Limits

\begin{tabular}{lll}
\hline Interval & Persentage & Cathegory \\
\hline $\mathbf{1}$ & $20 \%-35,99 \%$ & Very Low \\
\hline $\mathbf{2}$ & $36 \%-51,99 \%$ & Low \\
\hline $\mathbf{3}$ & $52 \%-67,99 \%$ & Moderate \\
\hline $\mathbf{4}$ & $68 \%-83,99 \%$ & High \\
\hline $\mathbf{5}$ & $84 \%-100 \%$ & Very High \\
\hline
\end{tabular}


Table-4. Results of Descriptive Calculation of Factors to test Someone's Readiness in using Fin-tech

\begin{tabular}{|c|c|c|c|c|}
\hline Dimension & $\begin{array}{l}\text { Item } \\
\text { Indicators }\end{array}$ & of Mean & Percentage & Cathegory \\
\hline \multirow[t]{11}{*}{ Optimism } & $\mathrm{X} 1$ & 3,56 & \multirow[t]{11}{*}{$73 \%$} & \multirow[t]{11}{*}{ High } \\
\hline & $\mathrm{X} 2$ & 3,80 & & \\
\hline & $\mathrm{X} 3$ & 3,89 & & \\
\hline & $\mathrm{X} 4$ & 3,61 & & \\
\hline & $\mathrm{X} 5$ & 3,80 & & \\
\hline & X6 & 3,82 & & \\
\hline & $\mathrm{X} 7$ & 3,06 & & \\
\hline & $\mathrm{X} 8$ & 3,56 & & \\
\hline & $\mathrm{X} 9$ & 3,67 & & \\
\hline & $\mathrm{X} 10$ & 3,53 & & \\
\hline & Mean & 3,63 & & \\
\hline \multirow[t]{8}{*}{ Innovativeness } & $\mathrm{X} 1$ & 3,25 & \multirow[t]{8}{*}{$68 \%$} & \multirow[t]{8}{*}{ High } \\
\hline & $\mathrm{X} 2$ & 3,28 & & \\
\hline & $\mathrm{X} 3$ & 3,14 & & \\
\hline & $\mathrm{X} 4$ & 3,30 & & \\
\hline & $\mathrm{X} 5$ & 3,77 & & \\
\hline & X6 & 3,74 & & \\
\hline & $\mathrm{X} 7$ & 3,41 & & \\
\hline & Mean & 3,41 & & \\
\hline \multirow[t]{11}{*}{ Discomfort } & $\mathrm{X} 1$ & 3,08 & \multirow[t]{11}{*}{$65 \%$} & \multirow[t]{11}{*}{ Moderate } \\
\hline & $\mathrm{X} 2$ & 3,14 & & \\
\hline & $\mathrm{X} 3$ & 3,23 & & \\
\hline & $\mathrm{X} 4$ & 3,16 & & \\
\hline & $\mathrm{X} 5$ & 3,51 & & \\
\hline & X6 & 3,15 & & \\
\hline & $\mathrm{X} 7$ & 3,49 & & \\
\hline & $\mathrm{X} 8$ & 3,38 & & \\
\hline & X9 & 3,41 & & \\
\hline & $\mathrm{X} 10$ & 3,06 & & \\
\hline & Mean & 3,26 & & \\
\hline \multirow[t]{10}{*}{ Insecurity } & $\mathrm{X} 1$ & 3,85 & \multirow[t]{10}{*}{$71 \%$} & \multirow[t]{10}{*}{ High } \\
\hline & $\mathrm{X} 2$ & 3,86 & & \\
\hline & $\mathrm{X} 3$ & 3,34 & & \\
\hline & $\mathrm{X} 4$ & 3,40 & & \\
\hline & $\mathrm{X} 5$ & 3,33 & & \\
\hline & X6 & 3,50 & & \\
\hline & $\mathrm{X} 7$ & 3,32 & & \\
\hline & $\mathrm{X} 8$ & 3,56 & & \\
\hline & X9 & 3,73 & & \\
\hline & Mean & 3,54 & & \\
\hline \multirow{2}{*}{$\begin{array}{l}\text { Perceived } \\
\text { usefulness }\end{array}$} & $\mathrm{X} 1$ & 3,65 & \multirow[t]{2}{*}{$73 \%$} & \multirow[t]{2}{*}{ High } \\
\hline & $\mathrm{X} 2$ & 3,64 & & \\
\hline
\end{tabular}




\begin{tabular}{|c|c|c|c|c|}
\hline & X3 & 3,72 & & \\
\hline & $\mathrm{X} 4$ & 3,61 & & \\
\hline & $\mathrm{X} 5$ & 3,64 & & \\
\hline & X6 & 3,61 & & \\
\hline & Mean & 3,64 & & \\
\hline \multirow{7}{*}{$\begin{array}{l}\text { Perceived ease of } \\
\text { use }\end{array}$} & $\mathrm{X} 1$ & 3,80 & \multirow[t]{7}{*}{$75 \%$} & \multirow[t]{7}{*}{ High } \\
\hline & $\mathrm{X} 2$ & 3,69 & & \\
\hline & X3 & 3,82 & & \\
\hline & $\mathrm{X} 4$ & 3,76 & & \\
\hline & X5 & 3,70 & & \\
\hline & X6 & 3,77 & & \\
\hline & Mean & 3,76 & & \\
\hline
\end{tabular}

Sources: IBM SPSS 24.0 (Data processed)

\section{In Table-4 it can be seen that:}

a. The optimism dimension of the factors to test one's readiness in technology on Fin-tech applications is in the "High" category. That is, in terms of dimensions of optimism, the respondents had high readiness.

b. The innovativeness dimension on factors for testing one's readiness in technology on Fintechapplications is in the "High" category. That is, in terms of innovativeness dimensions, the respondents had high readiness.

c. Discomfort dimensions on factors to test one's readiness in technology on Fin-tech applications are in the "Medium" category. That is, in terms of discomfort dimensions, the respondents had moderate readiness.

d. The dimensions of insecurity on factors to test one's readiness in technology on Fin-tech applications are in the "High" category. That is, in terms of insecurity dimensions, the respondents have high readiness.

e. The perceived usefulness dimension on factors to test one's readiness in technology on Fintechapplications is in the "High" category. That is, in terms of perceived usefulness dimensions, the respondents have high readiness.

a. Dimensions of perceived ease of use on factors to test one's readiness in technology in the Fin-techapplication are in the "High" category. That is, in terms of dimensions perceived ease of use, the respondents had high readiness.

b. The dimensions of perceived ease of use have the highest value, with an average of 3.76, while the dimension of discomfort has the lowest value, with an average of 3.26.

\subsection{Factor Analysis}

The steps taken in factor analysis are:

1. Measurement of whether or not enough samples use Kaiser-Meyer-Oklin (KMO). If the $\mathrm{KMO}$ value is inthe range of 0.5 to 1 , the sampling is sufficient and feasible.

2. Compilation of correlation matrices between variables, using Bartlett's test of sphericity if the value is large (>0.05), indicating a high correlation.

3. Determination of the number of factors using eigenvalues $>1$.

4. Determining the location of each statement item into a factor with the use of rotation component matrix. 
In Table-4 it can be seen that the observed sample is said to be sufficient for further analysis due to the value of Kaiser Meyer Olkin (KMO) $0.612>0.50$ and the Bartlett value $0.00<0.05$. This means that the distribution of questionnaires regarding the factors to test one's readiness in technology in the FIN-TECH application to 176 respondents fulfilled the sample adequacy requirements.

Table-5. Value of Eigenvalues

\begin{tabular}{llll}
\hline \multirow{2}{*}{ Factors } & \multicolumn{2}{l}{ Initial Eigenvalues } & \\
\cline { 2 - 3 } & Total & \% of Variance & Cumulative $\%$ \\
\hline $\mathbf{1}$ & 2,008 & $33,471 \%$ & $33,471 \%$ \\
\hline $\mathbf{2}$ & 1,173 & $19,555 \%$ & $53,027 \%$ \\
\cline { 1 - 3 } &, 923 & $15,380 \%$ & \\
\cline { 1 - 3 } &, 828 & $13,802 \%$ & \\
$\mathbf{5}$ &, 580 & $9,670 \%$ & \\
\hline $\mathbf{6}$ &, 487 & $8,122 \%$ & \\
\hline
\end{tabular}

Sources: IBM SPSS 24.0 (Data Processed)

\section{Conclusion}

a. There are 2 factors that can be used to test a person's readiness in technology on the Fintechapplication.

b. Factor 1 can explain variable variations that can be used to test a person's readiness in technology in the Fin-tech application by $33.5 \%$.

c. Factor 2 can explain variable variations that can be used to test a person's readiness in technology in the Fin-tech application by $19.6 \%$.

d. Both factors can explain variable variations that can be used to test a person's readiness in technology in the Fin-tech application by 53\%, with information loss of $47 \%$.

e. The names of these two factors cannot be determined before looking at the matrix rotation component table 5. As displayed above the benefits of Fin-tech for the community are consumers can enjoy better and faster services. Besides that, even more choices and do not need to be too difficult to come to the financial services office. In addition, consumers also enjoy using cashless. For companies and financial institutions, they can simplify the transaction process. The community can also reduce operational costs and capital.

Empirically, based on the processed data, the results show that Fin-tech Industry 4.0's innovation is important in digital payment transactions. The results also show that with fintech transactions must consider the security and convenience of transactions. Meanwhile, fintech has an impact on the use of digital money as cashless.

\section{Acknowledgments}

The researchers would like to thank the Research and Community Development (CRCD) Universitas Pelita Harapan, Karawaci, Tangerang Indonesia for financially supporting the research. 


\section{References}

[1] J. Purba, H. Hery, and P. Purba, "Usage ICT Application for Bundling Products: Strategic Digital Marketing in Facing the 4.0 Technology," in Proceedings of the The 1st International Conference on Computer Science and Engineering Technology Universitas Muria Kudus, 2018.

[2] J. D. Tan, J. T. Purba, and A. E. Widjaya, "Financial Technology as an Innovation Strategy for Digital Payment Services in the Millenial Generation," in Proceedings of the 1st Aceh Global Conference (AGC 2018), 2019.

[3] J. T. Purba, "Service Performance ICT Train New Technologies towards Organizations: Case Study Asindo," in Seminar Nasional, Business in Society: Towards Asian Era, 2014.

[4] J. T. Purba, "Applied ICT Innovation Services of Academic Information System: Strategy for Higher Educational Management," in International Conference of Organizational Innovation (ICOI), 2015.

[5] J. T. Purba, "Service Management Strategy by Implementing Academic Information Systems in Indonesia Higher Education," in International Seminar 11th Insyma, 2014.

[6] B. A. Harahap, P. B. Idham, A. C. M.Kusuma, and R. N. Rakhman, "Perkembangan Financial Technology terkait Central Bank Digital Currency (CBDC) terhadap Transmisi Kebijakan Moneter dan Makroekonomi,”WP/2/2017, 2017.

[7] Bank Indonesia, "Kajian Stabilitas Keuangan-Mitigasi Risiko Sistemik untuk Menjaga Stabilitas Sistem Keuangan dan Mendorong Intermediasi di Tengah Tantangan Global dan Domestik," KSK Maret, 2016.

[8] World Economic Forum, "Beyond Fin-tech: How the Successes and Failures of New Entrants Are Reshaping the Financial System," 2017.

[9] P. P. Wibowo, "Innovation \&Fin-tech Development in Retail Payment System in Indonesia," 2107.

[10] Makarim and Taira, "The Rise of Financial Technology in Indonesia," Makarim.com. [Online]. Available: http://www.makarim.com/uploads/997184_ Advisory\%2520\%2520The\%2520Rise\%2520Of\%2520-Financial\%2520Technology\%2520In\%2520Indonesia\%2520.

[11] J. T. Purba and R. Panday, "Innovation Strategy Services Delivery: An Empirical Case Study of Academic Information Systems in Higher Education Institution," in International Conference on Soft Computing, Intelligence Systems, and Information Technology, 2015, pp. 514-525.

[12] J. T. Purba and R. Panday, Innovation Strategy Services Delivery: An Empirical Case Study of Academic Information Systems in Higher Education Institution. 2015.

[13] J. T. Purba, "Pengukuran Kualitas Layanan Unit Kerja Teknologi Informasi Menuju Strategi Tata Kelola Organisasi: Studi Kasus," in Seminar Nasional, Fakultas Ekonomi Universitas Maranatha, 2014.

[14] Otoritas Jasa Keuangan, "Penyelenggara Fin-tech Terdaftar di OJK per Desember 2018," Otoritas Jasa Keuangan. [Online]. Available: https://www.ojk.go.id/id/beritadan-kegiatan/publikasi/Pages/Penyelenggara-Fin-tech-Terdaftar-di-OJK-perDesember-2018.aspx.

[15] "International Association of Insurance Supervisors (IAIS)." Organisation for Economic Co-Operation and Development ( $\{$ OECD $\})$, Nov-2016.

[16] D. Varga, "Fin-tech, the new era of financial services," Vez. / Budapest Manag. Rev., vol. 48, no. 11, pp. 22-32, Nov. 2017. 
[17] G. Dorfleitner, L. Hornuf, M. Schmitt, and M. Weber, Fin-tech in Germany. Cham: Springer International Publishing, 2017.

[18] K. Kamaludin and J. T. Purba, "Strategic Management Banking Technology Readiness Analysis in Facing Challenges and Opportunities," in Proceedings of the International Conference on Economics and Banking 2015, 2015.

[19] Chien-Hsin Lin, Hsin-Yu Shih, P. J. Sher, and Yen-Li Wang, "Consumer adoption of e-service: integrating technology readiness with the technology acceptance model," in A Unifying Discipline for Melting the Boundaries Technology Management:, 2005, pp. 483-488.

[20] F. D. Davis, "Perceived Usefulness, Perceived Ease of Use, and User Acceptance of Information Technology," MIS Q., vol. 13, no. 3, p. 319, Sep. 1989.

[21] X. Meng et al., "Cyclization of the Acyl Glucuronide Metabolite of a Neutral Endopeptidase Inhibitor to an Electrophilic Glutarimide: Synthesis, Reactivity, and Mechanistic Analysis," J. Med. Chem., vol. 50, no. 24, pp. 6165-6176, Nov. 2007.

[22] J. F. Hair, R. E. Anderson, R. L. Tatham, and W. C. (1 Black, Multivariate data analysis. (5th ed.). New Jersey: Prentice-Hall, 1998.

[23] I. Ghozali, Aplikasi Analisis Multivariate dengan Program IBM SPSS 21 Update PLS Regresi. Semarang: Badan Penerbit Universitas Diponegoro, 2013. 